\title{
Correction to: Viral time capsule: a global photo-elicitation study of child and adolescent mental health professionals during COVID-19
}

\author{
Olivia D. Herrington ${ }^{1}$, Ashley Clayton ${ }^{2}$, Laelia Benoit ${ }^{3}$, Cecil Prins-Aardema ${ }^{4,5}$, Madeline DiGiovanni ${ }^{1}$, \\ Indigo Weller ${ }^{6}$ and Andrés Martin ${ }^{5,7^{*}}$
}

\section{Correction to: Child Adolesc Psychiatry Ment Health (2021) 15:5 https://doi.org/10.1186/s13034-021-00359-5}

Following publication of the original article [1], the authors identified errors in affiliation and in the conclusion section. The following corrections are presented with this erratum:

In the conclusion, the first sentence should read, "Photoelicitation provided a disarming and efficient means to learn about individual, regional, and global similarities and differences regarding the professionals charged with addressing the mental health needs of children and adolescents during 4 early months of the COVID-19 global pandemic".

The original article [1] has been updated.
USA. ${ }^{7}$ Child Study Center, Yale School of Medicine, 230 South Frontage Road, New Haven, CT 06520-7900, USA.

Published online: 27 February 2021

Reference

1. Herrington OD, Clayton A, Benoit L, Prins-Aardema C, DiGiovanni M, Weller I, Martin A. Viral time capsule: a global photo-elicitation study of child and adolescent mental health professionals during COVID-19. Child Adolesc Psychiatry Ment Health. 2021;15:5. https://doi.org/10.1186/s1303 4-021-00359-5.

\section{Publisher's Note}

Springer Nature remains neutral with regard to jurisdictional claims in published maps and institutional affiliations.

\begin{abstract}
Author details
${ }^{1}$ Yale School of Medicine, New Haven, CT, USA. ${ }^{2}$ Department of Psychiatry, Yale School of Medicine, New Haven, CT, USA. ${ }^{3}$ Public Health and Sociology, Inserm (Institut National de La Santé Et de La Recherche Médicale) and CESP (Centre de Recherche en Epidémiologie et Santé Des Populations), Paris, France. ${ }^{4}$ GGZ Drenthe (Geestelijke Gezondheids Zorg: Mental Health Care), Beilen, The Netherlands. ${ }^{5}$ Center for Educational Development and Research in Health Sciences (CEDAR), University Medical Center Groningen, Groningen, The Netherlands. ${ }^{6}$ Bioethics Program, Harvard University, Cambridge, MA,
\end{abstract}

The original article can be found online at https://doi.org/10.1186/s1303 4-021-00359-5.

${ }^{*}$ Correspondence: andres.martin@yale.edu

${ }^{7}$ Child Study Center, Yale School of Medicine, 230 South Frontage Road, New Haven, CT 06520-7900, USA

Full list of author information is available at the end of the article

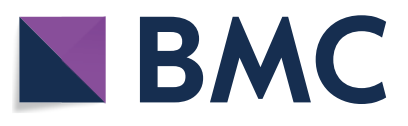

(c) The Author(s) 2021. This article is licensed under a Creative Commons Attribution 4.0 International License, which permits use, sharing, adaptation, distribution and reproduction in any medium or format, as long as you give appropriate credit to the original author(s) and the source, provide a link to the Creative Commons licence, and indicate if changes were made. The images or other third party material in this article are included in the article's Creative Commons licence, unless indicated otherwise in a credit line to the material. If material is not included in the article's Creative Commons licence and your intended use is not permitted by statutory regulation or exceeds the permitted use, you will need to obtain permission directly from the copyright holder. To view a copy of this licence, visit http://creativeco mmons.org/licenses/by/4.0/. The Creative Commons Public Domain Dedication waiver (http://creativecommons.org/publicdomain/ zero/1.0/) applies to the data made available in this article, unless otherwise stated in a credit line to the data. 